\title{
Antagonisme Trichoderma spp. terhadap Jamur Rigidoporus lignosus (Klotzsch) Imazeki dan Penekanan Penyakit Jamur Akar Putih pada Tanaman Karet
}

\author{
Endah Yulia ${ }^{1}$, Noor Istifadah ${ }^{1}$, Fitri Widiantini ${ }^{1}$ dan Hilda Sandra Utami ${ }^{2}$ \\ ${ }^{1}$ Departemen Hama dan Penyakit Tumbuhan, Fakultas Pertanian, Universitas Padjadjaran \\ ${ }^{2}$ Alumnus DHPT, Fakultas Pertanian, Universitas Padjadjaran \\ *Alamat korespondensi: endah.yulia@unpad.ac.id
}

\section{ABSTRACT \\ Antagonisms of Trichoderma spp. against Rigidoporus lignosus (Klotzsch) Imazeki and Supression of White Root Disease on Rubber Plant}

\begin{abstract}
White root disease caused by the infection of fungal pathogen Rigidoporus lignosus is an important disease on rubber plants. The pathogen infects the rubber roots but then might cause leaf drop or even kill the plants. Common control method used in controlling the disease is the application of synthetic fungicides besides increasing application of biological control agents (BCA) as an alternative control method. Trichoderma spp. is frequently used as BCA to control diseases in many plants. The aims of this study were to test the antagonism of Trichoderma spp. against $R$. lignosus and to assess the effectiveness of Trichoderma spp. corn starter in white root disease suppression on rubber seedlings. Trichoderma spp. The antagonism test was conducted using dual culture method in in vitro test. A randomized block design (RBD) experimental design was used in the glass house trial consisted of five treatments and five replications. Application of the Trichoderma spp. corn starter was combined with the application of compost in the treatments of $25 \mathrm{~g} \mathrm{BCA}+100 \mathrm{~g}$ of compost, $50 \mathrm{~g} \mathrm{BCA}+200 \mathrm{~g}$ of compost, $75 \mathrm{~g} \mathrm{BCA}+300 \mathrm{~g}$ of compost, $100 \mathrm{~g}$ of BCA $+400 \mathrm{~g}$ of compost, and a control treatment without BCA. The BCA Trichoderma spp. was applied in the same time with the inoculation of $20 \mathrm{~g}$ of corn mass culture of $R$. lignosus. The result of antagonism test showed that Trichoderma spp. isolate was effectively suppressed micelial growth of $R$. lignosus with the supperession percentage reached $90.82 \%$. Meanwhile, the Trichoderma spp. BCA in corn starter was also suppressed the disease development on rubber seedlings with the highest disease suppression of $100 \%$ at the dose of $100 \mathrm{~g} \mathrm{BCA} /$ seedling.
\end{abstract}

Keywords: Trichoderma spp., biocontrol agents, white root disease, rubber

\begin{abstract}
ABSTRAK
Penyakit jamur akar putih (JAP) merupakan penyakit penting pada tanaman karet. Penyakit ini disebabkan oleh infeksi patogen Rigidoporus lignosus pada akar tanaman karet yang dapat mengakibatkan daun gugur atau bahkan matinya tanaman. Pengendalian yang umum dilakukan adalah pengendalian kimia dengan menggunakan pestisida sintetik tetapi penggunaan agens biokontrol (ABK) juga telah mulai banyak dilakukan. Penggunaan Trichoderma spp. sebagai ABK telah banyak dilakukan untuk mengendalikan penyakit pada beberapa tanaman dengan hasil yang memuaskan. Penelitian ini bertujuan untuk menguji antagonisme Trichoderma spp. terhadap jamur $R$. lignosus dan penekanan penyakit JAP pada bibit tanaman karet yang diberi perlakuan starter jagung pecah Trichoderma spp. Pengujian antagonisme dilakukan secara in vitro melalui metode dual culture. Percobaan rumah kaca dilakukan dengan menggunakan Rancangan Acak Kelompok (RAK) yang terdiri atas lima perlakuan dan lima ulangan. Aplikasi starter Trichoderma spp. dilakukan dengan tambahan kompos pada perlakuan $25 \mathrm{~g}$ ABK $+100 \mathrm{~g}$ kompos, $50 \mathrm{~g}$ ABK $+200 \mathrm{~g}$ kompos, $75 \mathrm{~g}$ ABK $+300 \mathrm{~g}$ kompos, $100 \mathrm{~g}$ ABK $+400 \mathrm{~g}$ kompos, dan perlakuan kontrol atau tanpa aplikasi ABK Trichoderma spp. Aplikasi ABK dilakukan bersamaan dengan inokulasi biakan massal jagung pecah jamur $R$. lignosus sebanyak $20 \mathrm{~g}$ /bibit. Hasil uji antagonisme menunjukkan isolat
\end{abstract}


Trichoderma spp. efektif menekan pertumbuhan $R$. lignosus dengan penekanan mencapai 90,82\%. Demikian juga dengan aplikasi starter jagung pecah Trichoderma spp. menunjukkan penekanan penyakit JAP pada bibit tanaman karet dengan penekanan penyakit mencapai $100 \%$ pada dosis 100 g ABK/bibit tanaman karet.

Kata Kunci: Trichoderma spp., agens biokontrol, jamur akar putih, karet

\section{PENDAHULUAN}

Karet merupakan komoditas perkebunan yang memiliki peran besar di dalam perekonomian Indonesia dengan hasil utama lateks yang digunakan terutama sebagai bahan baku industri karet (Janudianto dkk., 2013; Pusari dkk., 2014). Di Indonesia, karet merupakan tanaman perkebunan penting terutama di tempat-tempat penanaman karet seperti Jambi, Sumatera, Riau, Kalimantan Barat, dan Jawa Barat. Permintaan pasar dunia terhadap karet alam semakin meningkat sehingga memberikan peluang yang tinggi bagi Indonesia untuk terus meningkatkan produksi dan volume ekspor (Ekanantari, 2015). Namun demikian, kebutuhan yang diinginkan seringkali tidak dapat dipenuhi oleh produksi yang tersedia yang diantaranya karena keberadaan pertanaman karet yang tidak produktif akibat mengalami kerusakan (Dinas Perkebunan Provinsi Jambi, 2012).

Banyak faktor yang berkontribusi terhadap menurunnya produksi karet yang salah satunya adalah rendahnya manajemen hama dan penyakit pada tanaman karet (Balai Pengkajian Teknologi Pertanian Riau, 2012). Dilaporkan bahwa keberadaan hama dan penyakit pada tanaman karet merupakan salah satu faktor utama penyebab menurunnya kualitas produksi tanaman karet termasuk infeksi jamur patogen Rigidoporus lignosus (Klotzsch) Imazeki yang merupakan penyebab penyakit jamur akar putih (JAP) (Semangun, 2008). Penyakit JAP telah banyak dilaporkan menimbulkan kerugian pada pertanaman karet dan dapat menjadi penyebab menurunnya produksi karet dengan kehilangan hasil mencapai 3-5\% pada perkebunan besar dan $5-15 \%$ pada perkebunan rakyat (Balai Penelitian Tanaman Industri dan Penyegar, 2014). Dinas Perkebunan Kalimantan Timur (2013) melaporkan kerugian mencapai 371 juta rupiah disamping kerugian lain berupa penurunan produktivitas tanaman karet. Sebelumnya dilaporkan bahwa intensitas serangan penyakit JAP pada tanaman karet belum menghasilkan di kebun komersial Sumatera Utara sebesar 0,8\% (Rahayu dkk., 2006).
Akar tunggang maupun akar lateral tanaman karet dapat diserang penyakit JAP dan jika intensitas penyakit cukup tinggi maka penyakit ini dapat mengakibatkan kematian tanaman terutama jika tanaman berumur 2-6 tahun (Dinas Perkebunan Kalimantan Timur, 2014). Infeksi penyakit dapat terjadi pada awal pembibitan, pada tanaman belum menghasilkan (TBM) atau pada tanaman menghasilkan (TM) (Balai Pengkajian Teknologi Pertanian Riau, 2012). Gejala penyakit JAP pada daun berupa daun yang menjadi berwarna kuning atau pucat dengan ujung daun terlipat ke dalam dan daun dapat gugur. Demikian juga dengan ujung ranting tanaman karet yang dapat mengalami kematian. Gejala pada akar tanaman yang terinfeksi berupa terdapatnya benang-benang jamur atau miselium yang berwarna putih dan juga struktur tahan jamur yang merupakan penebalan miselium. Pada serangan berat, akar tanaman akan membusuk dan tanaman akan mudah tumbang. Janudianto dkk. (2013) menyebutkan bahwa penyebaran penyakit JAP terutama melalui kontak akar tanaman sakit ke tanaman di sekitarnya.

Pengendalian secara kimia dengan menggunakan pestisida sintetik merupakan pengendalian penyakit JAP yang umum dilakukan dengan cara aplikasi pestisida disiramkan atau ditaburkan pada tanah pada parit-parit yang disiapkan di daerah leher akar disamping pengendalian lain seperti penggunaan beleran dan pembongkaran tunggul (Purwanta dkk., 2008). Namun demikian, pengendalian secara kimia ini dianggap cukup mahal dan penggunaan pestisida sintetik dalam jangka panjang dipercaya dapat menimbulkan efek samping yang merugikan terhadap lingkungan dan kesehatan manusia (Ismail \& Tenrirawe, 2010). Pengendalian penyakit JAP yang lebih ramah lingkungan telah dilaporkan sebelumnya misalnya penggunaan tanaman penutup tanah dan pemanfaatan agens biokontrol (ABK). Trichoderma spp. pernah digunakan pada tanaman karet sebagai pupuk biologis dan dilaporkan dapat meningkatkan produksi karet hingga 25\% (Dinas Perkebunan Kalimantan Timur, 2014). Pemanfaatan agens biokontrol seperti Trichoderma spp. dilaporkan memiliki banyak keunggulan 
diantaranya aman, tidak terakumulasi dalam rantai makanan, dan tidak berpengaruh terhadap jasad bukan sasaran (Nurhayati, 2011; Octriana, 2011; Susanti, 2015; Waluyo, 2004).

Trichoderma spp. dilaporkan bersifat antagonis terhadap patogen tanah, patogen permukaan inang seperti biji, benih, dan juga patogen pada bagian tanaman terinfeksi. Mekanisme pengendalian jamur Trichoderma spp. diantaranya mikoparasit, kompetisi ruang atau nutrisi, antibiosis atau enzimatis, maupun kemungkinan induksi resistensi inang terhadap patogen (Harjono dkk., 2001; Rogério et al., 2009). Enzim yang dihasilkan Trichoderma spp. dapat melarutkan dinding sel patogen dan juga menghasilkan dua jenis antibiotik seperti gliotoksin dan viridian dimana kedua antibiotik ini dapat berinteraksi dengan jamur Trichoderma spp. sehingga mampu menekan penyakit (El-Katatny et al., 2001). Spesies jamur $T$. virens dapat bersaing cepat dengan patogen karena mengeluarkan antibiotik dari senyawa viridiol fitotoksin yang dapat menghambat perkembangan patogen, memarasit patogen dengan melakukan penetrasi langsung, lebih cepat menggunakan oksigen, air, dan nutrisi (Kinerley \& Mukherjee, 2010).

Trichoderma spp. ini telah diformulasikan sebagai biofungisida terdaftar untuk pengendalian hayati beberapa patogen pada tanaman pertanian maupun kehutanan (Direktorat Pupuk dan Pestisida, 2001). Secara sederhana, aplikasi Trichoderma spp. di lapangan umumnya dalam bentuk bahan pembiakan masal atau starter. Hal ini dilakukan untuk menghindari pengaruh lingkungan yang ekstrim dan untuk menjamin keberlangsungan hidup Trichoderma spp. terutama ketika pertama kali diaplikasikan di lapangan. Dilaporkan bahwa keefektifan dan kelangsungan hidup Trichoderma spp. dipengaruhi langsung oleh faktor lingkungan. Sifat starter baik komposisi atau kandungan senyawa substrat maupun lama waktu simpan dilaporkan akan memengaruhi kualitas $A B K$ seperti viabilitas ABK (James \& Jaronski, 2000). Penelitian ini bertujuan untuk menguji antagonime Trichoderma spp. dalam media jagung pecah terhadap $R$. lignosus dan penekanan penyakit JAP pada bibit tanaman karet.

\section{BAHAN DAN METODE}

Penelitian dilaksanakan di rumah kaca dan Laboratorium Fitopatologi, Departemen Hama dan Penyakit Tumbuhan, Fakultas Pertanian, Universitas
Padjadjaran. Penelitian dilaksanakan dengan menggunakan metode eksperimen dengan Rancangan Acak Kelompok (RAK) dengan lima perlakuan dan lima ulangan. Di dalam setiap perlakuan di dalam satu ulangan terdiri atas 3 bibit tanaman sehingga terdapat 75 bibit tanaman karet yang diuji. Setiap tanaman percobaan diinokulasi jamur $R$. lignosus pada media biakan jagung pecah sebanyak $20 \mathrm{~g} / \mathrm{bibit}$ tanaman. Perlakuan pada penelitian ini adalah:

1. Starter Trichoderma spp. $25 \mathrm{~g} / \mathrm{bibit}$ karet

2. Starter Trichoderma spp. $50 \mathrm{~g} / \mathrm{bibit}$ karet

3. Starter Trichoderma spp. $75 \mathrm{~g} /$ bibit karet

4. Starter Trichoderma spp. $100 \mathrm{~g} /$ bibit karet

5. Kontrol tanpa pemberian starter Trichoderma spp.

Perhitungan Kerapatan, Penyiapan Biakan Murni dan Identifikasi Trichoderma spp.

Kerapatan konidia Trichoderma spp. dilakukan dengan menggunakan metode pengenceran (serial dilution) dan dihitung menggunakan haemocytometer. Produk starter jagung pecak ABK Trichoderma spp. diperoleh dari Balai Proteksi Tanaman Perkebunan (BPTP) Bandung, Jawa Barat. Biakan jamur tersebut sebelumnya telah diinkubasi selama 14 hari (kemasan 100 g starter sudah penuh terkolonisasi). Pada pengujian sebelumnya menunjukkan bahwa ABK Trichoderma spp. masih memiliki keefektifan yang tinggi setelah disimpan 14 hari. Starter Trichoderma spp. diidentifikasi untuk memastikan keberadaan jamur Trchoderma spp. pada starter yang diuji. Jamur yang telah dibiakan pada media jagung pecah diisolasi pada media PDA $(1 \mathrm{~cm} \times 1 \mathrm{~cm})$ di atas object glass dan ditutup menggunakan cover glass. Isolat tersebut disimpan selama 2-4 hari dalam cawan petri yang tertutup rapat menggunakan plastic wrap. Identifikasi dilakukan dengan mengamati karakter morfologi dan struktur Trichoderma spp. secara makroskopik dan mikroskopik di bawah mikroskop dengan bantuan buku identifikasi Barnett \& Hunter (1987).

\section{Penyiapan Biakan Murni $R$. lignosus}

Biakan murni jamur $R$. lignosus diperoleh dari Balai Penelitian Proteksi Tanaman Perkebunan Provinsi Kalimantan Barat yang kemudian diperbanyak untuk keperluan penelitian. Jamur $R$. lignosus ini ditumbuhkan pada media PDA yang diberi antibiotik $1 \mathrm{mg} / \mathrm{ml}$ chloramphenicol. Biakan diinkubasikan selama 5-14 hari. Jamur $R$. lignosus ini kemudian dipersiapkan dalam medium biakan 
masal jagung pecah yang diinkubasikan selama 2-3 minggu sebelum inokulasi.

\section{Pengujian Antagonisme Jamur Trichoderma spp. terhadap Jamur $R$. lignosus}

Uji antagonisme dengan menggunakan metode dual culture. Jamur $R$. lignosus dan Trichoderma spp. masing-masing ditumbuhkan pada media PDA selama 7 hari pada suhu ruang. Biakan kedua jamur tersebut kemudian dipotong dengan menggunakan cork borer berukuran diameter 0,5 $\mathrm{cm}$. Kedua jamur tersebut kemudian diletakkan pada media PDA yang baru secara bersebrangan. Jamur $R$. lignosus ditumbuhkan tanpa jamur Trichoderma spp. sebagai perlakuan kontrol. Pengamatan dilakukan terhadap pertumbuhan $R$. lignosus dengan cara mengukur diameter miselia $R$. lignosus yang tumbuh pada perlakuan dan kontrol setelah dinkubasikan selama tujuh hari.

\section{Pengujian Kemampuan Trichoderma spp. dalam Mengendalikan Penyakit JAP}

Bibit karet yang digunakan adalah bibit berumur 15 bulan yang diperoleh dari Dinas Perkebunan Provinsi Jawa Barat dengan jenis klon PB 260. Bibit karet ini ditanam pada polybag dengan kapasitas $2 \mathrm{~kg}$ tanah. ABK Trichoderma spp. diaplikasikan dengan cara dicampur dengan kompos dengan berat kompos sebanyak 4 kali lipat dari berat masing-masing perlakuan yang diuji dan diinkubasi selama 3 hari. Penambahan kompos tersebut umum dilakukan petani sebelum aplikasi Trichoderma spp. di lapangan, serta manfaat kompos sebagai media pertumbuhan yang baik bagi ABK tersebut. Dengan demikian, jumlah kompos yang diberikan untuk setiap perlakuan adalah:

1. Starter Trichoderma spp. $25 \mathrm{~g} /$ bibit karet + kompos $100 \mathrm{~g}$

2. Starter Trichoderma spp. $50 \mathrm{~g} /$ bibit karet + kompos $200 \mathrm{~g}$

3. Starter Trichoderma spp. $75 \mathrm{~g} /$ bibit karet + kompos $300 \mathrm{~g}$

4. Starter Trichoderma spp. $100 \mathrm{~g} /$ bibit karet + kompos $400 \mathrm{~g}$

5. Kontrol tanpa pemberian Trichoderma spp. + kompos

Media tanam yang digunakan adalah campuran $2 \mathrm{~kg}$ tanah yang telah disterilisasi dengan kompos dengan perbandingan 1:1. Campuran tanah dan kompos tersebut ditimbang sebanyak $2 \mathrm{~kg}$ dan dimasukkan ke dalam polybag berukuran 25 x 25 $\mathrm{cm}$. Aplikasi starter jagung pecah Trichoderma spp. dilakukan dengan cara mengeruk tanah di sekitar pangkal batang dan perakaran bibit karet hingga mencapai kedalaman $5 \mathrm{~cm}$. Kemudian area dari pangkal batang ke atas diberi batas dari $3 \mathrm{~cm}$ pangkal batang ke atas dan $2 \mathrm{~cm}$ pangkal batang ke bawah menggunakan spidol. Pada area tersebut diinokulasikan biakan massal jamur $R$. lignosus sebanyak $20 \mathrm{~g}$, kemudian area inokulasi ini ditutupi dengan campuran Trichoderma spp. dan kompos yang telah diinkubasikan dan ditutup kembali dengan tanah. Pada perlakuan kontrol, tidak diberikan campuran ABK Trichoderma spp. dan kompos, tetapi bibit diinokulasi dengan $R$. lignosus.

Pengamatan pada akar dilakukan dengan menghitung persentase kejadian penyakit dan intensitas penyakit. Kejadian penyakit dihitung pada setiap bibit tanaman karet yang diuji dengan cara membandingkan jumlah akar yang terserang dengan jumlah akar seluruhnya. Perhitungan intensitas penyakit pada akar dilakukan dengan menghitung persentase kolonisasi jamur $R$. lignosus pada akar yang terserang dalam skala $0-5$ yaitu $0=$ tidak terjadi kolonisasi, $1=0<\mathrm{x} \leq 10 \%$ kolonisasi akar, $2=11<\mathrm{x}$ $\leq 25 \%$ kolonisasi akar, $3=26<\mathrm{x} \leq 50 \%$ kolonisasi akar, $4=51<\mathrm{x} \leq 75 \%$ kolonisasi akar dan $5=76<\mathrm{x}$ $\leq 100 \%$ kolonisasi akar. Hasil skoring kemudian dimasukkan ke dalam rumus sebagai berikut:

Intensitas penyakit $=\frac{\sum(\mathrm{nxz})}{\mathrm{N} \times \mathrm{Z}} \times 100 \%$

Keterangan:

$\mathrm{n}=$ Jumlah akar yang memiliki nilai skor yang sama

$\mathrm{z}$ = Nilai skor

$\mathrm{N}$ = Jumlah total akar yang diamati

$\mathrm{Z}=$ Nilai skor tertinggi yang ditetapkan

\section{HASIL DAN PEMBAHASAN}

\section{Karakteristik Isolat dan Kerapatan Konidia Trichoderma spp.}

Isolat jamur yang diperoleh dari starter diidentifikasi sebagai Trichoderma spp. berdasarkan karakteristik morfologi dan struktur jamur (Barnet \& Hunter, 1987; Kubicek \& Harman, 1998). Pertumbuhan jamur tegolong cepat dengan pertumbuhan miselium ke dalam media dan aerial miselium, koloni awalnya berwarna putih yang kemudian nampak warna hijau yang merupakan bantalan (cushion) kelompok konidia dengan tekstur miselium seperti wol (wolly). Konidifor tidak berwarna dan bercabang dengan fialid tunggal atau berkelompok, konidia tidak berwarna dan tidak bersekat, konidia berbentuk bulat yang diproduksi dalam cluster di ujung fialid. 
Rata-rata kerapatan konidia yang diperoleh adalah $6,85 \quad \mathrm{x} \quad 10^{7} \quad$ konidia $/ \mathrm{ml}$. Direktorat Perlindungan Perkebunan (2014) menyebutkan bahwa kerapatan spora yang sesuai standar untuk ABK Trichoderma spp. yaitu harus memiliki nilai lebih besar atau sama dengan $1 \times 10^{6}$ konidia $/ \mathrm{ml}$. Dengan demikian, dari kerapatan konidia yang diperoleh menunjukkan bahwa jumlah konidia yang ada pada starter yang diuji memenuhi persyaratan mutu ABK. Dilaporkan bahwa kerapatan spora yang tinggi atau memenuhi standar akan menjadi indikator kemampuan ABK dalam menekan infeksi patogen (Syahnen dkk., 2014).

Uji Antagonisme Jamur Trichoderma spp. terhadap Jamur $R$. lignosus

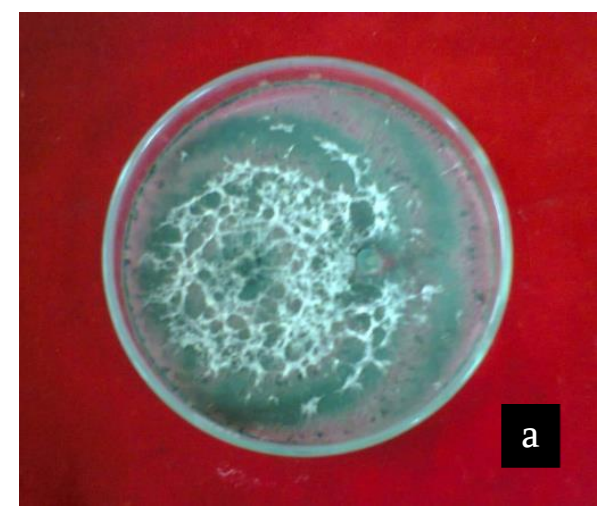

Hasil menunjukkan bahwa isolat Trichoderma spp. mampu menekan pertumbuhan jamur $R$. lignosus secara pada metode dual culture. Pertumbuhan $R$. lignosus menjadi sangat terhambat oleh pertumbuhan koloni Trichoderma spp. yang sangat cepat (Gambar 1). Dengan demikian, mekanisme penekanannya terutama berupa kompetisi ruang meskipun ditemukan juga zona penghambatan (antibiosis) dan melanisasi hifa pada beberapa kasus. Hasil perhitungan rata-rata jari-jari koloni patogen $R$. lignosus pada perlakuan kontrol pada empat belas hari setelah inokulasi adalah sebesar 5,83 $\mathrm{cm}$ dibandingkan dengan pada perlakuan dengan Trichoderma spp. dengan ratarata sebesar 0,54 cm. Dengan demikian, Trichoderma spp. dapat menghambat pertumbuhan $R$. lignosus secara in vitro sebesar $90,82 \%$.

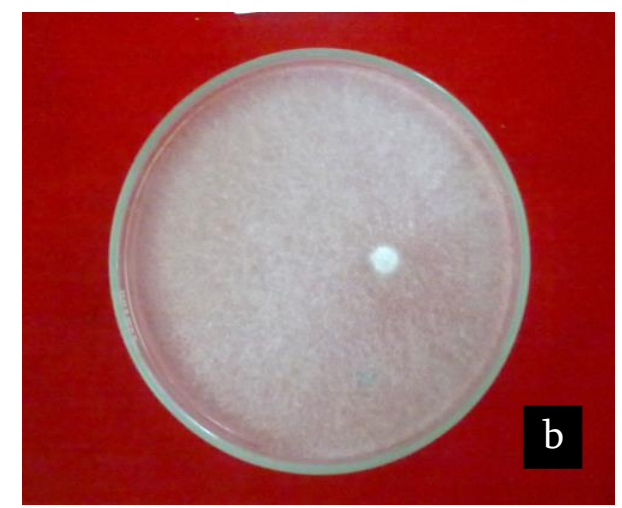

Gambar 1. Uji antagonisme metode dual culture Trhichoderma sp. terhadap R. lignosus. (a) Pertumbuhan koloni $R$. lignosus yang terhambat oleh pertumbuhan koloni Trichoderma spp. (b) Pertumbuhan koloni $R$. lignosus tanpa Trichoderma spp. pada perlakuan kontrol.

Howell (2003) dan Belete et al., (2015) menyebutkan bahwa jamur Trichoderma spp. memiliki banyak mekanisme di dalam proses pengendalian patogen. Jamur Trichoderma spp. mengkolonisasi akar, rizosfer tanaman, dan menekan patogen dengan berbagai mekanisme seperti kompetisi, mikoparasit, memproduksi antibiotik, dan induksi resisten. Di dalam penelitian ini, mekanisme kompetisi ABK Trichoderma spp. terutama berupa kompetisi yang ditunjukkan dengan kecepatan pertumbuhan Trichoderma spp. yang mengakibatkan ketersediaan nutrisi dan ruang bagi patogen lebih sedikit. Mekanisme lainnya yaitu mikoparasit, dimana jamur Trichoderma spp. mampu mengenali dan memparasiti hifa patogen, menggunakan haustoria untuk menyerap nutrisi dan menembus dinding sel patogen menggunakan enzim seperti kitinase, glukanase, dan protease (Gajera et al., 2013). Mekanisme antibiosis Trichoderma spp. adalah dihasilkannya senyawa sekunder seperti viridin, trikomidin, dan gliotoksin yang biasanya dikombinasikan dengan enzim pendegradasi dinding sel sehingga mampu melakukan penetrasi ke dalam hifa patogen yang bersifat antibiosis (Ajitha \& Lakshmidevi, 2010; El-Katatny et al., 2001; Howell, 2003). Pada penelitian ini, pembentukan zona penghambatan dapat diperkirakan sebagai hasil dari mekanisme antibiosis.

\section{Uji Penekanan Penyakit Jamur Akar Putih oleh Trichoderma spp.}

Hasil menunjukkan adanya kolonisasi jamur $R$. lignosus pada akar bibit tanaman karet yang diuji. Selain pada perlakuan kontrol, kolonisasi jamur $R$. lignosus pada akar bibit tanaman karet ditemukan juga pada beberapa bibit tanaman karet yang diberi perlakuan Trichoderma spp. tetapi dengan luas kolonisasi yang lebih rendah dan lapisan miselium 
yang lebih tipis dibandingkan lapisan miselium yang tebal dan banyak pada perlakuan kontrol. Dilaporkan bahwa tanaman yang terinfeksi jamur ini akarnya akan diselubungi jamur $R$. lignosus berwarna putih pada bagian permukaan akar dimana miselium akan menempel pada akar (rizomorf) hingga menyerupai akar tanaman (Pusat Penelitian dan Pengembangan Perkebunan, 2014). Trichoderma spp. dilaporkan berperan sebagai ABK melalui mekanisme antibiosis, mikoparasit, kompetisi ruang, dan kompetisi nutrisi. Mekanisme dari ABK jamur Trichoderma spp. ini yang memungkinkan terjadinya penekanan penyakit JAP pada bibit tanaman karet. Infeksi jamur $R$. lignosus disebutkan ditandai dengan adanya kolonisasi pada bagian tanaman terinfeksi dan infeksi ini dihasilkan dari penetrasi yang berulang-ulang (Omorusi, 2011). Jamur $R$. lignosus akan melakukan penetrasi dan mengkolonisasi jaringan akar dan kemudian mendegradasi dinding sel dengan mengeluarkan enzim dan melakukan penyerapan nutrisi yang akhirnya dapat merusak jaringan akar (Gieger et al., 1986 dalam Nicole \& Benhamou, 1991; Jayasuria, 2004; Oghenekaro, 2016).

Pengamatan kejadian dan intensitas penyakit JAP dilakukan pada 90 hari setelah aplikasi (HAS). Hasil menunjukkan kejadian dan intensitas penyakit JAP pada perlakuan kontrol lebih tinggi daripada pada perlakuan ABK Trichoderma spp. Pada Tabel 1 dapat dilihat bahwa semua dosis ABK Trichoderma spp. yang diuji berbeda nyata secara statistik dengan perlakuan kontrol. Hasil menunjukkan bahwa perlakuan ABK Trichoderma spp. mampu menekan penyakit JAP pada akar bibit tanaman karet dengan penekanan tertinggi sebesar $100 \%$ pada perlakuan $100 \mathrm{~g} \mathrm{ABK} /$ bibit tanaman karet. Hal ini menunjukkan bahwa perlakuan dosis jamur ABK Trichoderma spp. yang tinggi dapat secara optimal menekan pertumbuhan jamur $R$. Lignosus meskipun penghambatan penyakit JAP yang tinggi juga diperoleh pada perlakuan $25 \mathrm{~g}$ $\mathrm{ABK} /$ bibit dengan persentase penghambatan sebesar 91,82\%. Hal ini menunjukkan bahwa starter Trichoderma spp. pada dosis yang rendah sudah menunjukkan keefektifannya pada penelitian ini sekaligus menunjukkan sifat aman dari penggunaan ABK Trichoderma spp. Dilaporkan bahwa dosis Trichoderma spp. yang diaplikasikan di lapangan dapat bervariasi. Trichoderma harzianum yang diaplikasikan sebanyak 45g/polybag efektif menekan penyakit layu fusarium (Alfizar dkk., 2011). Pada percobaan dosis dan aplikasi di lapangan, dilaporkan bahwa aplikasi jamur Trichoderma spp. sebanyak 25 $\mathrm{g} /$ bibit dalam polybag dan $600 \mathrm{~kg} / \mathrm{ha}$ pembibitan di lapangan terbukti efektif (Rahayu et al., 2007; Sujatno \& pawirosoemardjo, 2001)

Secara umum, intensitas penyakit JAP yang terjadi pada penelitian ini tergolong rendah. Hal ini dapat diperkirakan karena waktu aplikasi ABK Trichoderma spp. dan inokulasi jamur patogen $R$. lignosus yang relatif singkat. Diperkirakan bahwa ABK starter Trichoderma spp. membutuhkan waktu lebih lama untuk menekan penyakit JAP secara optimal. Novita (2011) menyebutkan bahwa pemberian ABK Trichoderma spp. ke daerah perakaran tanaman dapat meningkatkan populasi mikroba antagonis di dalam tanah sehingga perkembangan patogen menjadi terhambat dan proses infeksi patogen semakin menurun pada waktu tertentu. Umumnya, mekanisme penekanan jamur Trichoderma spp. tidak secara langsung mematikan patogen tetapi hanya menekan perkembangannya sehingga pada aplikasi ABK Trichoderma spp. biasanya masih ditemukan kejadian penyakit tetapi akan lebih rendah daripada perlakuan kontrol (Soenartiningsih dkk., 2014).

Tabel 1. Kejadian, intensitas dan penghambatan penyakit JAP pada akar bibit tanaman karet yang diberi perlakuan Trichoderma spp. pada 90 hari setelah aplikasi

\begin{tabular}{lccc}
\hline Perlakuan & $\begin{array}{c}\text { Kejadian } \\
\text { penyakit (\%) }\end{array}$ & $\begin{array}{c}\text { Intensitas } \\
\text { penyakit (\%) }\end{array}$ & $\begin{array}{c}\text { Penghambatan } \\
\text { penyakit (\%) }\end{array}$ \\
\hline Starter Trichoderma spp. 25 g/bibit karet + kompos 100 g & $1,25 \mathrm{a}$ & $0,22 \mathrm{a}$ & 91,82 \\
Starter Trichoderma spp. $50 \mathrm{~g} /$ bibit karet + kompos $200 \mathrm{~g}$ & $1,60 \mathrm{a}$ & $0,32 \mathrm{a}$ & 88,10 \\
Starter Trichoderma spp. 75 g/bibit karet + kompos $300 \mathrm{~g}$ & $2,00 \mathrm{a}$ & $0,40 \mathrm{a}$ & 85,13 \\
Starter Trichoderma spp. 100 g/bibit karet + kompos 400 & $0,00 \mathrm{a}$ & $0,00 \mathrm{a}$ & 100 \\
g & $13,46 \mathrm{~b}$ & $2,69 \mathrm{~b}$ & - \\
Kontrol tanpa pemberian Trichoderma spp. + kompos & 100 \\
\hline
\end{tabular}

Keterangan: Nilai rata-rata yang diikuti oleh huruf yang sama tidak berbeda nyata antar perlakuan pada taraf $5 \%$ menurut uji Duncan Multiple Range Test (DMRT). 
Kemampuan jamur Trichoderma spp. dalam menghambat patogen tanaman telah banyak dilaporkan. Aplikasi pada bagian atas tanaman menunjukkan keefektifan Trichoderma spp. termasuk $T$. virens dalam mengendalikan penyakit downy mildew dan patogen Phytophthora palmivora pada buah kakao (Nurhayati dkk., 2012; Umrah dkk., 2009). Dilaporkan mampu menekan perkembangan. Pada patogen tular tanah, Trichoderma spp. (T. harzianum dan T. hamatum) dilaporkan efektif mengendalikan Rigidoporus microporus dengan persentase penghambatan mencapai 81,85\% (Berlian dkk., 2013; Kaewchai \& Soytong, 2010). Beberapa spesies Trichoderma seperti $T$. hamatum, $T$. virens, $T$. amazonicum, dan T. atroviride secara in vitro maupun pada bibit tanaman karet dilaporkan dapat menekan perkembangan penyakit JAP lebih dari 80\% (Amaria dkk., 2013; Suwandi, 2008). Penelitian lain menunjukkan mengaplikasikan T. harzianum dapat menekan penyakit JAP pada tanaman karet dengan tingkat penekanan lebih dari $40-60 \%$ yang ditunjukkan pada 60-90 hari setelah aplikasi (Jayasuriya \& Thennakoon, 2007). Bagwan (2010) melaporkan Trichoderma spp. disebutkan efektif mengendalikan jamur Sclerotium rolfsii, Aspergillus niger dan Aspergillus flavus.

Media biakan jagung pecah yang digunakan di dalam penelitian ini diperkirakan telah mendukung keberlangsungan hidup Trichoderma spp. Disebutkan bahwa pertumbuhan Trichoderma spp. dalam media biakan dipengaruhi oleh kandungan nutrisi seperti karbon, nitrogen, dan karbohidrat sederhana dimana jamur Trichoderma spp. membutuhkan glukosa sebagai sumber karbon utama (Pusat Penelitian dan Pengembangan Perkebunan, 2011; Widyastuti dkk., 2002). Ketersediaan sumber gula pada jagung pecah mampu meningkatkan pertumbuhan dan perkembangan jamur Trichoderma spp. Demikian juga dengan pemberian kompos yang dicampurkan dengan starter Trichoderma spp. pada penelitian ini diperkirakan secara tidak langsung berperan di dalam penekanan penyakit JAP. Dilaporkan bahwa bahan organik yang terkandung dalam kompos dapat memiliki manfaat ganda sebagai sumber nutrisi bagi ABK serta mampu menekan penyakit terbawa tanah (Noble \& Conventury, 2005).

\section{SIMPULAN}

Jamur Trichoderma spp. mampu menekan jamur $R$. lignosis pada pengujian in vitro dengan penekanan mencapai 90,82\%. Starter Trichoderma spp. mampu menekan penyakit JAP pada bibit tanaman karet dengan persentase penghambatan penyakit tertinggi sebesar $100 \%$ pada perlakuan 100 g ABK/bibit tanaman karet.

\section{UCAPAN TERIMAKASIH}

Penelitian ini merupakan kerjasama Fakultas Pertanian Universitas Padjadjaran dan Dinas Perkebunan Provinsi Jawa Barat. Peneliti mengucapkan terimakasih kepada Dinas Perkebunan Provinsi Jawa Barat atas kerjasama yang dilakukan serta penyediaan dana penelitian.

\section{DAFTAR PUSTAKA}

Ajitha, PS and N Lakshmedevi. 2010. Effect of volitile and von-volitile compounds from Trichoderma spp. against Colletotrichum capsici incitant of anthracnose on bell peppers. Nature and Science. 8: 265-296.

Alfizar, Marlina, dan H Nurul. 2011. Upaya pengendalian penyakit layu Fusarium oxysporum dengan pemanfaatan agen hayati cendawan FMA dan Trichoderma harzianum. Jurnal Floratek. 6: 8-17.

Amaria, W, E Taufik, dan R Harni. 2013. Seleksi dan identifikasi jamur antagonis sebagai agens hayati jamur akar putih (Rigidopuros microporus) pada tanaman karet. Buletin Riset Tanaman Rempah dan Aneka Tanaman Industri. 4(1): 1-8.

Bagwan, NB. 2010. Evaluation of biocontrol potential of Trichoderma species against Sclerotium rolfsii, Aspergillus niger and Aspergillus flavus. International Journal of Plant Protection. 4(1): 107-111.

Balai Penelitian Tanaman Industri dan Penyegar. 2014. Jamur Akar Putih Penyakit Berbahaya pada Perkebunan Karet. Tersedia online pada http://balittri.litbang.pertanian.go.id. Diakses tanggal 21 Maret 2016.

Balai Pengkajian Teknologi Pertanian Riau. 2012. Pengendalian Jamur Akar Putih pada Budidaya Karet. Tersedia online pada http://riau.litbang.pertanian.go.id. Diakses tanggal 25 Oktober 2015.

Barnett, HL and BB Hunter. 1987. Illustrated Genera of Imperfect Fungi. $4^{\text {th }}$ Eds. MacMillan Publishing Company. New York.

Belete, E, A Ayalew, and S Ahmed. 2015. Evaluation of local isolates of Trichoderma spp. against 
black root rot (Fusarium solani) on faba bean. J Plant Pathol Microb 6: 279. Doi:10.4172/2157-7471.1000279.

Berlian, I, B Setyawan, dan H Hadi. 2013. Mekanisme antagonisme Trichoderma spp. terhadap beberapa patogen tular tanah. Warta Perkaretan, Sungei Putih. 32(2): 7482.

Dinas Perkebunan Provinsi Jambi. 2012. Statistik perkebunan provinsi jambi 2011. Tersedia online pada http://disbun.jambiprov.go.id. Diakses pada tanggal 20 Mei 2016.

Direktorat Pupuk dan Pestisida. 2001. Pestisida untuk Pertanian dan Kehutanan. Direktorat Jenderal Bina Sarana Pertanian. Departemen Pertanian. Jakarta.

Ekanantari. 2015. Outlook Karet Komoditas Pertanian Subsektor Perkebunan. Pusat Data dan Sistem Informasi Pertanian. Jakarta.

El-Katatny, MH, M Gudelj, KH Robra, MA ElElnaghy, and GM Gubitz. 2001. Characterizatuon of a chitinase and 1,3glucanase from Trichoderma harzianum T24 involved in control of the phytopathogen Sclerotium rolsfii. Appl. Microbiol. Biotechnol. 56: 137-143.

Gajera, H, R Domadiya, S Patel, M Kapopara, and B Golakiya. 2013. Molecular mechanism of Trichoderma as bio-control agents against phytopathogen system-a review. Current Research in Microbiology and Biotechnology. 1(4): 133-142.

Harjono, SM Widyastuti, dan S Margino. 2001. Pemurnian dan karakterisasi enzim endokitinase dari agen pengendali hayati Trichoderma reesei. Jurnal Perlindungan Tanaman Indonesia. 7(2): 114-120.

Howell, CR. 2003. Mechanisms employed by Trichoderma species in the biological control of plant diseases: The history and evolution of current concepts. Plant Disease. 87(1): 1-10.

Ismail, $\mathrm{N}$ dan A Tenrirawe. 2010. Potensi Agens Hayati Trichoderma spp. sebagai Agens Pengendali Hayati. Seminar Regional Inovasi Teknologi Pertanian. Balai Pengkajian Teknologi Pertanian, Sulawesi Utara.

James, RR and S Jaronski. 2000. Effect of low viability on inefectivity of Beauveria bassiana conidia toward the silverleaf whitefly. J. Invertbr. Pathol. 77: 99-107.
Janudianto, A Prahmono, H Napitupulu, dan S Rahayu. 2013. Panduan Budidaya Karet untuk Petani Skala Kecil. Rubber Cultivation Guide for Small-Scale Farmers. Lembar Informasi AgFor 5. Bogor, Indonesia: World Agroforestry Centre (ICRAF) Southeast Asia Regional Program.

Jayasuria, KE. 2004. Factors affecting disease tolerance of rubber tree and research needs for developing disease tolerant genotypes for the sustainability of rubber industry. Bulletin of the Rubber Institute of Sri Lanka. 45: 1-10.

Jayasuriya, KE and BI Thennakoon. 2007. Biological control of Rigidoporus microporus, the cause of white root disease in rubber. Cey. J. Sci. (Bio. Sci.). 36(1): 9-16.

Kaewchai, S and K Soytong. 2010. Application of biofungicides against Rigidoporus microporus causing white root disease of rubber trees. Journal of Agric. Tech. 6(2): 349-363.

Kinerley, CM and P Mukherjee. 2010. Trichoderma virens. Tersedia online pada http://genome.jgi.pdf.org. Diakses tanggal 31 Oktober 2015.

Kubicek, CP, and GE Harman. 1998. Trichoderma and Gliocladium Volume 1: Basic Biology, Taxonomy and Genetic. Taylor \& Francis, Ltd. London.

Nicole, MR and N Benhamou. 1991. Cytochemical aspects of cellulose breakdown during the infection process of rubber tree roots infected by Rigidoporus lignosus. Phytopathology. 81: 1412-1419.

Noble, R and E Conventury. 2005. Suppression of soilborne plant disease with compost: A review. Biocontrol Science and Technology. 15: 3-20.

Novita, T. 2011. Trichoderma sp. dalam pengendalian penyakit layu fusarium pada tanaman tomat. Biospecies. 4(2): 27-29.

Nurhayati, U Abu, dan EA Silvia. 2012. Aplikasi Trichoderma virens melalui penyemprotan pada daun, akar, dan perendaman akar untuk menekan infeksi penyakit downy mildew pada tanaman caisin. Dharmapala. 4:22-28.

Nurhayati. 2011. Penggunaan jamur dan bakteri dalam pengendalian penyakit tanaman secara hayati yang ramah lingkungan. Prosiding Semirata Bidang Ilmu-Ilmu 
Pertanian BKS-PTN Wilayah Barat 316321.

Octriana, L. 2011. Potensi Agen hayati dalam menghambat pertumbuhan Phytium sp. secara in vitro. Buletin Plasma Nutfah. 17(2): 138-142.

Oghenekaro, AO. 2016. Molecular Analysis of the Interaction between White Rot Pathogen (Rigidoporus microporus) and Rubber Tree (Hevea brasiliensis). Department of Forest Sciences Faculty of Agriculture and Forestry, Helsinki.

Omorusi, VI, EE Omo-Ikerodah and MUB Mokwunye. 2011. Evaluation of effect of antagonistic fungi, and arbuscular mychorhizal fungi (AMF) on incidences of some disease of Hevea brasiliensis (Muell, Arg.). Nature and Science. 9 (12): 151-154.

Purwanta, JH, Kiswanto, dan Slameto. 2008. Teknologi Budidaya Karet. Badan Penelitian dan Pengembangan Pertanian.Bandar Lampung, Indonesia.

Pusari, D dan S Haryanti. 2014. Pemanenan getah karet (Hevea brasiliensis Muell. Arg) dan penentuan kadar karet kering (KKK) dengan variasi temperatur pengovenan di pt. Djambi waras jujuhan kabupaten bungo, jambi. Buletin Anatomi dan Fisiologi. 22(2): 64-74.

Pusat Penelitian dan Pengembangan Perkebunan. 2014. Pengendalian Penyakit Jamur Akar Putih (JAP) pada Pembibitan Karet dengan Trichoderma sp. Tersedia pada http://perkebunan.litbang.pertanian.go.id. Diakses tanggal 12 November 2015.

Rahayu, S, S Pawirosoemardjo, dan Sujatno. 2007. Biological control of white root disease of Hevea rubber using Trichoderma-based biofungicide Trico SP ${ }^{\text {PLus }}$. Proc. Int. Work. White Root Dis. Hevea Rubb. Indonesian Rubber Research Institute.

Rahayu, S, Soekiman, dan Sujatno. 2006. Pengendalian penyakit jamur akar putih pada tanaman karet secara biologi dengan biofungisida triko spp. ${ }^{\text {lus. Pusat Penelitian }}$ Karet. Tersedia online pada http://sitp.rpn.co.id/uploads/riset/karet. Diakses tanggal 25 Oktober 2015.

Rogério, EH, AWV Pomella, W Soberanis, LL Loguercio, and JO Pereira. 2009. Biocontrol potential of Trichoderma martiale against the black-pod disease (Phytophthora palmivora) of cacao. Biological Control. 50: 143-149.

Semangun, H. 2008. Penyakit-Penyakit Tanaman Perkebunan di Indonesia. Gadjah Mada University Press. Yogyakarta.

Soenartiningsih, N Djaenuddin, dan MS Saenong. 29014. Efektivitas Trichoderma sp. dan Gliocladium sp. sebagai agen biokontrol hayati penyakit busuk pelepah daun pada jagung. Penelitian Pertanian Tanaman Pangan. 33(2): 129-135.

Sujatno, dan S Pawirosoemardjo. 2001. Pengenalan teknik pengendalian penyakit jamur akar putih pada tanaman karet secara terpadu. Warta Puslit Karet. 20(1-3): 64-75.

Susanti, Y. 2015. Pengendalian Hayati Penyakit Jamur Akar Putih (JAP) pada Tanaman Karet Secara In Vitro dengan Menggunakan Trichoderma spp. Lokal Kabupaten Rokan Hulu. Tersedia online pada http://pmbpasca.ipb.ac.id. Diakses tanggal 25 Oktober 2015.

Suwandi, 2008. Evaluasi kombinasi isolat Trichoderma mikoparasit dalam mengendalikan penyakit akar putih pada bibit karet. Jurnal HPT Tropika. 8(1): 55-62.

Syahnen, DDN Sirait, dan SE Pinem. 2014. Teknik Uji Mutu Agens Pengendali Hayati (ABK) di Laboratorium. Balai Besar Perbenihan dan Proteksi Tanaman Perkebunan (BBPPTP) Medan.

Umrah, $\mathrm{T}$ Anggraeni, RR Esyanti, dan INP Aryantha. 2009. Antagonisitas dan efektivitas Trichoderma sp. dalam menekan perkembangan Phytophthora palmivora pada buah kakao. Jurnal Agroland. 16(1): 916.

Waluyo. 2004. Pengembangan Trichoderma harzianum sebagai bahan pengendalian penyakit tanaman. Makalah Pelatihan Pemurnian dan Penstabilan Agens Hayati. Dinas Perkebunan, Yogyakarta.

Widyastuti, SM, Sumardi, Irfa'i, HH Nurjanto. 2002. Aktivitas penghambatan Trichoderma spp. terformulasi terhadap jamur patogen tular tanah secara in-vitro. Jurnal Perlindungan Tanaman Indonesia. 8(1): 27-39. 